Maurer School of Law: Indiana University

Digital Repository @ Maurer Law

1989

\title{
A Probit Model of NLRB Bargaining Order Cases in the Appellate Courts
}

Terry A. Bethel

Indiana University Maurer School of Law, bethel@indiana.edu

C. A, Melfi

Follow this and additional works at: https://www.repository.law.indiana.edu/facpub

Part of the Labor and Employment Law Commons

\section{Recommended Citation}

Bethel, Terry A. and Melfi, C. A, "A Probit Model of NLRB Bargaining Order Cases in the Appellate Courts" (1989). Articles by Maurer Faculty. 2463.

https://www.repository.law.indiana.edu/facpub/2463

This Article is brought to you for free and open access by the Faculty Scholarship at Digital Repository @ Maurer Law. It has been accepted for inclusion in Articles by Maurer Faculty by an authorized administrator of Digital Repository @ Maurer Law. For more information, please contact rvaughan@indiana.edu. 


\title{
A Probit Model of NLRB Bargaining Order Cases in the Appellate Courts
}

\author{
C.A. MELFI and T.A. BETHEL* \\ Indiana University, Bloomington, IN 47405
}

This study examines NLRB bargaining orders that have gone to appeals courts and ascertains what factors influence whether or not the order is enforced and to what degree these factors influence the likelihood of enforcement. Substantial information has been collected from each reported appellate decision that reviewed $N L R B$ bargaining orders issued over a four-year period. A probit regression model is employed to examine whether factors related to an employer's unfair labor practice campaign are involved in the circuit court's enforcement decisions or if more weight is given to unrelated factors, such as the circuit in which the appeal is heard or the amount of judicial delay involved in the appeals process.

\section{Introduction}

The basic policy of the National Labor Relations Act is one of majority rule: Unions typically acquire representational rights by convincing a majority of employees that such representation is in their best interests. Unions then may seek voluntary recognition from the employer or petition for an election conducted by the National Labor Relations Board. Employers frequently resist the organizational efforts of unions, and during the campaign period preceding the election the employer and the union compete for employees' support through speeches, letters, and other forms of propaganda. If an employer's campaign practices threaten employees or otherwise interfere with their ability to exercise free choice, the NLRB usually conducts a re-run election and orders the employer to stop the unlawful campaign practices. Sometimes, however, the NLRB determines that, despite its order to cease and desist, the employer has created such a coercive atmosphere that a subsequent election will be affected. In those instances, the NLRB may remedy an employer's unlawful conduct by ordering it to bargain with the union; this is commonly called a Gissel bargaining order. ${ }^{1}$ The order is issued even though the union may have lost the election and, until recently, even though there was no indication that the union had support from a majority of

\footnotetext{
*Funding for this research was supported by NSF Grant SES-86-18517.

'The name comes from the Supreme Court's opinion in NLRB v. Gissel Packing Co., 395 U.S. 575 (1969), in which the Court upheld the Board's authority to impose remedial bargaining orders.
} 
employees. ${ }^{2}$ The NLRB's assumption is that such orders protect the rights of employees by denying to employers the fruits of their illegal conduct and by establishing the very relationship that the conduct sought to destroy.

The courts of appeals review a large number of bargaining order cases. This finding by itself is not surprising. NLRB remedial orders are not self-executing. If an employer fails or refuses to comply with an order, the Board's only recourse is to petition for enforcement in the appellate courts. ${ }^{3}$ Moreover, the employer in bargaining order cases has engaged in unusually serious unfair labor practices, and the Board might believe that judicial enforcement is appropriate to encourage compliance.

Similarly, "any person aggrieved" by the issuance of the Board's remedial order, such as the employer against whom the order operates, can petition the court for review. ${ }^{4}$ Given the controversial nature of the bargaining order remedy and given that such orders typically issue only against employers who have fought vigorously against a union, it might be expected that these employers will use the review process as an additional avenue of avoiding, or at least of delaying, the bargaining obligation.

This study examines bargaining orders that have gone to the appeals courts and will ascertain which factors influence whether or not a bargaining order is enforced and to what degree these factors influence the likelihood of enforcement. We have collected substantial information from each reported appellate decision that reviewed NLRB bargaining orders issued over a four-year period. In what follows, we examine whether factors related to the employer's unfair labor practice campaign are involved in the circuit court's enforcement decision or whether more weight is given to unrelated factors, such as the circuit in which the appeal is heard or the amount of judicial delay involved in the appeals process. We also examine whether or not factors specifically mentioned by the appeals courts in reaching their decisions agree with our empirical findings.

\section{Bargaining Orders in the Appellate Courts}

Under the National Labor Relations Act, both the existence of and the remedies for unfair labor practices are matters entrusted primarily to the discretion of the NLRB. As the Supreme Court has said, "Congress could not catalogue all the

\footnotetext{
${ }^{2}$ At issue in Gissel was the NLRB's authority to impose a bargaining order as a remedy for an employer's serious unfair labor practices when the union had once demonstrated majority support through signed authorization cards. In Conair Corp., 261 NLRB 1189 (1982), enforcement denied, 721 F. 2d 1355 (D.C. Cir. 1983), the Board claimed authority to issue a bargaining order as a remedy for particularly egregious employer conduct, even in the absence of a showing of union majority status. Conair was overruled by the Board in Gourmet Foods, Inc., 270 NLRB 578 (1984). For a fuller discussion of the issues raised by these cases, see Bethel (1984).
}

${ }^{3}$ See Section 10(e) of the National Labor Relations Act, 29 U.S.C. $\$ 160(\mathrm{e})$.

${ }^{4}$ See Section 10(f) of the NLRA, 29 U.S.C. \$160(f). 
devices and strategies for circumventing the policies of the Act. Nor could it define the whole gamut of remedies to effectuate the policies in an infinite variety of specific situations." The responsibility to both identify and redress unfair labor practices, therefore, was assigned to the Board "as one of those agencies presumably equipped or informed by experience to deal with a specialized field of knowledge," 6 with its decisions being subject to only limited judicial review. Moreover, Supreme Court decisions make it clear that the Board's expertise is entitled to considerable deference by the courts, particularly with respect to the formulation of remedies.

By statute, the courts of appeals have the power to enforce the Board's orders, to modify them, or to set them aside. Board findings of fact, if supported by substantial evidence, are conclusive. ${ }^{7}$ Still, there have been numerous requests by the appellate courts that the Board devise a set of standards or guidelines controlling the issuance of bargaining orders. A review of the courts' opinions, however, indicates that they, too, are guilty of inconsistency in their enforcement of the Board's orders. ${ }^{8}$

Both the circuit courts and the Board are reluctant to frustrate employees' free choice by forcing an unwanted union on them. Therefore, especially if the union has lost a representation election, there must be sufficient evidence to indicate that the outcome of the election was a response to the employer's anti-union actions rather than a reflection of actual employee sentiment.

It is difficult to categorize the type of employer misconduct that results in a bargaining order. Among the unfair labor practices committed by an employer during a union organizing campaign are "hallmark" violations. These unfair labor practices are said to "go to the heart of the [National Labor Relations] Act" by reinforcing employees' awareness of their employer's control over the workers' economic destiny, thereby enabling the employer to dictate the employees' actions regarding union organization. These violations include discriminatory discharge, threat of plant closure, threat of discharge, promise of benefits, grant of benefits, and plant closure.

Briefly, discriminatory discharge refers to an employer's firing or layoff of employees in retaliation for their support of a union. Threat of plant closure and threat of discharge are either overt or implied threats to close the plant or to discharge employees if union activities are not stoppped. An employer promises or grants benefits as incentives for employees to cease their organizational efforts.

\footnotetext{
'Phelps Dodge Corp. v. NLRB, 313 U.S. 177, 194 (1941).

'Universal Camera Corp. v. NLRB, 340 U.S. 474, 488 (1951).

'See Section 10(e) of the NLRA, 29 U.S.C. $\$ 160(\mathrm{e})$.

${ }^{8}$ See Bethel and Melfi (1988) for a thorough analysis of the opinions of appeals courts in bargaining order cases.
} 
Examples of such benefits include wage increases, increased break time, and better holiday and vacation privileges. Finally, plant closure refers to an employer's temporary or permanent shutdown, specifically as a reaction to union organizational efforts. Although the commission of one or more hallmark violations does not guarantee the issuance of a bargaining order, the absence of all such unfair labor practices does not preclude an order to bargain.

Besides the hallmark violations, other factors enter into the assessment of the appropriateness of a bargaining order in any particular case. These factors include the other unfair labor practices committed by the employer, ${ }^{9}$ the number of employees in the bargaining unit, the strength of employee support for the union, and factors specific to each case pertaining to the organizational campaign period. The task of the NLRB is to determine whether or not an employer's actions are pervasive enough to prevent the conduct of a fair election, thus necessitating a bargaining order. Otherwise, the employer is ordered to cease his unfair labor practices, and a second (or first) election is ordered.

Of the 176 Gissel orders issued from 1979 to 1982,108 were reviewed by the courts of appeals. Of those, the court enforced the Board's order in 70.4 percent of the cases. When bargaining orders are reviewed, with the employer, the NLRB, or even both as petitioner, the appeals courts' authority is to determine if the Board abused its discretion by issuing the order. If the court determines that the order was justified, the bargaining order is enforced. The proportion of bargaining orders that are enforced varies over time, but the orders are enforced more often than not. Insight into what determines whether or not a bargaining order will be enforced is gained by perusing the opinions of the circuit courts for cases in which bargaining orders have and have not been enforced.

One factor that might influence whether or not a bargaining order is enforced is the employer's unfair labor practice campaign. The presence of any of the hallmark violations, except perhaps plant closure, should have a positive effect on the probability of enforcement. If a plant closes, and the shutdown is not temporary, then the court of appeals might be less likely to uphold a bargaining order, because there would be no employer with whom to bargain. ${ }^{10}$ It is difficult to predict which of the remaining violations would have the largest impact on the probability of enforcement.

\footnotetext{
'Common unfair labor practices (besides hallmark violations) committed by employers include employee surveillance or impression of surveillance, employee interrogation, physical violence, overly broad no distribution-no solicitation rules, and statements that bringing in a union would be futile. Any employer action that interferes with employees' rights to organize is considered an unfair labor practice.

${ }^{10}$ Such enforcement decisions, however, are not entirely useless. It is clear, for example, that employers must bargain with the unions that represent their employees over the effect on employees of the business closure. See, for example, First National Maintenance Corp. v. NLRB, 452 U.S. 666 (1981). Presumably, however, a union would have little leverage to extract concessions (such as severance pay) from an employer who had already ceased operations.
} 
Discriminatory discharge might be perceived as producing different effects in different cases. For example, it is likely that the discharge of leading union advocates or of a significant percentage of the bargaining unit would chill the organizational interest of the remaining employees. In contrast, as the court noted in NLRB v. Loy Food Stores, Inc. $d / b / a$ Ken's IGA, ${ }^{11}$ the firing of two "teenage goof off" employees was thought to be "not likely to intimidate the adult workforce." In short, discriminatory discharges might not produce the same coercive effect in all cases, or the court of appeals' assessment of the effect of a discriminatory discharge might differ from the NLRB's assessment. Still, it is likely that the presence of one or more discriminatory discharges will add to the probability that a bargaining order will be enforced.

Similarly, the grant of benefits could have differing effects on the probability of enforcement in different cases. If the benefit granted was a substantial wage increase to all employees, for example, then this might be more likely to preclude a fair election than would either a small wage increase or the granting of a fiveminute increase in break time. The category "grant of benefits," therefore, includes factors that increase the probability of enforcement with differing degrees of impact. A parallel argument holds with respect to the promise of benefits.

Threats of discharge and threats of closure are likely to have fairly similar effects regardless of the characteristics of the bargaining units. The number of employees in the unit, however, might cause such threats to have differing effects and might affect the perceived severity of other unfair labor practices. The issue of unit size is discussed below. One additional observation is that these threats can either be overt or implied. Whether or not threats are implied is a judgmental decision, but the courts and the NLRB had little disagreement over this issue for the sample under consideration. Again, the presence of either of these hallmark violations is expected to increase the probability that a bargaining order will be enforced.

If the appellate courts are showing deference to the Board's assessment of the effect of hallmark violations, then the presence of these violations should have no effect on the probability of enforcement. Courts, however, often make their own assessments as to the effects of employers' unfair labor practice campaigns. That is, the courts often mention one or more of the employer's unfair labor practices in justifying their decision of whether or not to enforce the Board's bargaining order. ${ }^{12}$ This implies that the presence of hallmark violations will affect the probability of enforcement of bargaining orders as discussed here.

Another interesting influence is the passage of time between the union's demand for recognition and the court of appeals decision. Courts have sometimes justified a failure to enforce bargaining orders by alluding to the "changed circumstances doctrine," which takes into account changes occurring between the time the Board issues its order and the time of the court's decision. When there is

"697 F. 2d 798 (7th Cir. 1983).

${ }^{12}$ See Bethel and Melfi (1988). 
significant delay, the court might also be influenced by changes that have occurred in the interval between the employer's unlawful conduct and the Board's order. Changed circumstances include both employee turnover and the restructuring or replacement of management personnel. In many such cases, the passage of time itself influences the court's decision.

Whether changed circumstances should be considered is a point on which the appellate courts disagree. Some courts, in enforcing bargaining orders, have specifically mentioned that changed circumstances should not be taken into account. If the presence of changed circumstances is a significant factor in the nonenforcement of a bargaining order, then the coefficient on the variable representing the number of months between the union's demand for recognition and the court's decision should be negative, indicating a dampening effect on the probability of enforcement. If changed circumstances do not matter in the determination of whether or not a bargaining order will be enforced, however, then the coefficient on the time lag would be close to zero. ${ }^{13}$

Although both the Board and the courts sometimes speculate about the impact of unfair labor practices on small bargaining units, it is not easy to predict the effect of unit size on the probability of enforcement. On the one hand, unfair labor practices might have a more significant impact on employees in a small bargaining unit. This consideration should increase the likelihood of enforcement in cases involving small bargaining units. This effect implies a negative value of the coefficient on unit size; that is, enforcement is more likely in cases involving small bargaining units. On the other hand, employee turnover during the delay between the demand for recognition and judicial review is expected to result in a higher employee replacement rate in a small unit than in a large one. High employee turnover is one of the changed circumstances that might detract from the likelihood of enforcing a bargaining order, implying a higher probability of enforcement in cases involving large bargaining units. Thus, the effect of unit size on the probability of enforcement is uncertain, a priori, and depends on which aspect of unit size has the stronger influence.

With respect to bargaining order cases, Gissel requires only that the union at some point demonstrate majority support. This being the case, it is not clear that the level of employee support should affect the probability that a bargaining order will be enforced. There is some indication, however, that the appeals courts take into consideration how much above a minimum majority the employee support was. If this is a factor in the appellate court decisions, then the empirical evidence should demonstrate that higher employee support results in a higher probability that a bargaining order will be enforced.

Differing attitudes among the twelve circuits toward bargaining orders can be accounted for by differentiating among the circuits in which the appellate cases

\footnotetext{
${ }^{13}$ For examples of cases on both sides of this debate, see Bethel and Melfi (1988).
} 
are decided. This would capture circuit-specific effects, such as whether or not any particular circuits are tougher or more lenient than others in the treatment of bargaining orders. The coefficients on the twelve circuits cannot be hypothesized a priori, except through casual observations about the circuits, gathered from reading the circuit courts' opinions in bargaining order cases. Based on such evidence, the Second Circuit and Seventh Circuit appear to have much lower enforcement rates than the other circuits; no circuits appeared to be noticeably lenient in the cases studied. Thus, negative coefficient estimates are expected on the variables representing the Second Circuit and Seventh Circuit.

\section{Data and Model Specification}

In order to address the questions posed above, we examined the population of all bargaining orders issued during fiscal years 1979 through $1982 .{ }^{14}$ Of the 176 NLRB bargaining orders issued during that period, the appeals courts reviewed 108. Of those appeals, the bargaining order was not enforced in 32 of the cases: of the 76 enforced bargaining orders, 27 were enforced by memorandum decisions. ${ }^{15}$ For the firms and unions involved in the 108 appealed cases, the following information was collected: unit size (number of employees in the bargaining unit); NLRB region ${ }^{16}$ in which the firm was located; the percentage of employees who signed authorization cards at the time that the union demanded recognition (or filed a petition); the time (in months) between the date of demand for recognition and the date the NLRB issued the bargaining order; the time (in months) between when the bargaining order was issued and the date of the court of appeals decision; the circuit and the outcome of the appellate case; and any unfair labor practices committed by the employer.

The information on employee support, region, unit size, time between demand for recognition and bargaining order, and unfair labor practices was collected from NLRB cases. Lexis (a computer assisted legal research service) and the NLRB's Classified Index to Decisions were used to identify all bargaining order cases within the study period. The remaining information was obtained from the court of appeals opinions. Names, definitions of, and descriptive statistics on the variables used are included in Table 1.

\footnotetext{
${ }^{14}$ This period runs from October 1, 1978, through September 30, 1982. Fiscal years are used rather than calendar years because the NLRB's records and statistics are maintained by fiscal years.

${ }^{15} \mathrm{~A}$ memorandum decision usually denotes an unpublished order, the results of which are merely noted in the Federal Reporter. Sometimes there is no official report of the court's action at all. In those cases, we have gathered data either from unofficial case reports (such as the Labor Relations Reference Manual) or from NLRB records that are available to the general public.

${ }^{16}$ The NLRB is a federal administrative agency headquartered in Washington, DC. The Board maintains more than 30 regional offices throughout the United States. These offices are under the supervision of the General Counsel, who acts as prosecutor in unfair labor practice cases. The primary activity of the regional offices is the investigation and prosecution of unfair labor practices and the holding of elections in representation cases.
} 
Table 1

Summary of Data

\begin{tabular}{|c|c|c|c|}
\hline Variable & $\begin{array}{c}\text { Sample } \\
\text { Proportion } \\
\text { or Mean }\end{array}$ & $\begin{array}{l}\text { Standard } \\
\text { Deviation }\end{array}$ & Range \\
\hline ENFORCE $(1=$ enforced, $0=$ not enforced $)$ & .70 & - & 0 or 1 \\
\hline UNSTRNGTH (\% authorization cards signed) & 65.53 & 14.13 & $46.0-100.0$ \\
\hline SIZE (\# employees in bargaining unit) & 76.57 & 123.57 & $2-1000$ \\
\hline $\begin{array}{l}D E M \text {-ORD (\# months between demand for rec. and } \\
\text { date of bargaining ord.) }\end{array}$ & 25.96 & 10.12 & $10.5-63.0$ \\
\hline $\begin{array}{l}O R D-A P P \text { (\# months between bargaining ord. and } \\
\text { appellate decision) }\end{array}$ & 16.48 & 6.60 & $6.0-43.0$ \\
\hline $\begin{array}{l}D E M-A P P \text { (\# months between demand for rec. and } \\
\text { appellate decision) }\end{array}$ & 42.44 & 12.94 & $23.5-92.0$ \\
\hline DISCHG $(1=$ discriminatory discharge, $0=$ none $)$ & 0.59 & - & 0 or 1 \\
\hline THRCLS $(1=$ threat of plant closure, $0=$ none $)$ & 0.47 & - & 0 or 1 \\
\hline THRDIS ( $1=$ threat of discharge, $0=$ none $)$ & 0.54 & - & 0 or 1 \\
\hline GRNTBEN (1 = grant of benefits, $0=$ none $)$ & 0.44 & - & 0 or 1 \\
\hline$P R O M B E N(1=$ promise of benefits, $0=$ none $)$ & 0.49 & - & 0 or 1 \\
\hline CLOSE $(1=$ plant closure, $0=$ none $)$ & 0.03 & - & 0 or 1 \\
\hline
\end{tabular}

The variable, ENFORCE, represents the observation of the answer "yes" or "no" to the question of whether or not each bargaining order was enforced. This variable is defined to equal one if the bargaining order was enforced and zero if not. The mean of ENFORCE, 0.70 , indicates that 70 percent of the 108 bargaining orders in the sample were enforced by the courts of appeals.

In order to test the hypothesis about the effect of unit size on the probability of a bargaining order being enforced, the variable, SIZE, was measured as the number of employees in the bargaining unit. This number often changes during the time between the union's demand for recognition and the court of appeals decision. When this was the case, the unit size at the date of the union's demand was used, because the union's majority status is usually measured as of the time of the demand. Unit size ranged from 2 to 1,000 , with 76.57 employees being the average size.

USTRNGTH, measured as a percentage, is used as an indication of employee support for the union. Because elections were not conducted in all of the cases examined in the study and because the elections held were "tainted" and do not accurately indicate support for the union, strength of employee support is measured as the number of authorization cards signed by employees in the bar- 
gaining unit (at the time of demand for recognition) divided by the total number of employees in the bargaining unit (SIZE). This percentage was a majority (i.e., between 50 and 100 ) in all except one case. ${ }^{17}$ Seven of the 108 observations on employee support for the union showed complete (100 percent) support.

It is worth noting that Cooper (1984) examined the appropriateness of using authorization cards as a measure of the amount of employee support for a union. Cooper found evidence to indicate that majority employee support, as measured using authorization cards, does not guarantee a union victory in an NLRBconducted election. This can be interpreted to demonstrate that the percentage of authorization cards signed overstates the level of employee support for the union. The average level of support for the unions in the cases studied is 65.53 percent. Interestingly, this is close to the percentage at which Cooper found there to be a 50-50 chance of a union winning an election.

The effect of a delay on the probability of enforcement was measured using the variables $D E M-O R D, O R D-A P P$, and $D E M-A P P$, which represent the number of months (to the nearest one-half month) between the union's demand for recognition (or, if no demand was made, the filing of a petition) and the NLRB decision, between the date of the NLRB decision and the court of appeals decision, and between the union's demand for recognition and the court of appeals decision. If the coefficient on any of these variables is positive and significant, then employers should be more eager to appeal the Board's decision in order to cause further delay, thus reducing the probability of enforcing the bargaining order. ${ }^{18}$ As can be seen in Table 1, several months or years can pass between a union's demand for recognition and a final decision by the court of appeals.

The variables DISCHG, THRCLS, THRDIS, PROMBEN, GRNTBEN, and $C L O S E$ represent hallmark violations. They are set equal to one if the violation was committed and zero if not. The unfair labor practices corresponding to these six variables are: discriminatory discharge (or layoff), threat of plant closure, threat of discharge, promise of benefits, grant of benefits, and plant closure. With any of the hallmark violations, it seems reasonable to assume that an employer's action would tend to undermine union support, thus making it more likely that a bargaining order will be enforced.

\footnotetext{
${ }^{17}$ The case in which a bargaining order was issued even though there was never any indication of majority support for the union is Conair Corporation, 261 NLRB 1189 (1982). Of the 176 bargaining orders issued by the NLRB during the sample period, there was one other in which there was no indication of majority support. United Dairy Farmers Cooperative, 257 NLRB 772 (1981) did not go to the court of appeals and is not included in our sample of 108 appealed cases. The Board overruled Conair and disclaimed its authority to issue non-majority bargaining orders in Gourmet Foods, Inc., 270 NLRB (1984).

${ }^{18}$ As noted previously, employers still have an incentive to appeal bargaining order decisions, even if there is little chance that the order will be overturned. This is because such employers want to put off the bargaining obligation as long as possible.
} 
The most frequently observed hallmark violation was discriminatory discharge, which was committed by 59 percent of the employers. This may be an indication that employers assume that the discharge of employees for union activity is an effective unfair labor practice for them to utilize. ${ }^{19}$ Close behind discriminatory discharge is the threat of discharge, committed by 54 percent of the employers. The least frequently used (and arguably the most drastic) hallmark violation was plant closure. Only 3 out of the 108 employers closed down, although 47 percent (51 employers) threatened to close. Finally, nearly half of the employers promised benefits to the employees in order to discourage support for a union, and 44 percent of the employers actually granted benefits to the employees for that purpose.

Table 2 summarizes the appellate courts' decisions, broken down according to the circuits in which the appeals were heard. The average enforcement rate for all circuits is 70.4 percent. The enforcement rates of only two circuits - the Second and the Seventh - are significantly different from the average. In both cases, the enforcement rates of the circuits are significantly lower than the overall enforcement rate. Accordingly, two variables, representing the Second and Seventh Circuits, are included in the estimating model. The expected signs of the

Table 2

Summary of Appellate Court Decisions

\begin{tabular}{|c|c|c|c|}
\hline Circuit & $\begin{array}{l}\text { Number of Cases } \\
\text { (out of 108) }\end{array}$ & $\begin{array}{l}\text { Number Enforced } \\
\text { (out of cases in } \mathrm{Cir} \text { ) }\end{array}$ & $\begin{array}{l}\text { Number Not Enforced } \\
\text { (out of cases in Cir) }\end{array}$ \\
\hline 1 & $(5.6 \%)$ & $4 \quad(66.7 \%)$ & $2(33.3 \%)$ \\
\hline 2 & $11(10.2 \%)$ & $5 \quad(45.5 \%)$ & $6 \quad(54.5 \%)$ \\
\hline 3 & $14(13.0 \%)$ & $12(85.7 \%)$ & $2(14.3 \%)$ \\
\hline 4 & $7 \quad(6.5 \%)$ & $4(57.1 \%)$ & $3 \quad(42.9 \%)$ \\
\hline 5 & $3 \quad(2.8 \%)$ & $3(100.0 \%)$ & $0 \quad(0.0 \%)$ \\
\hline 6 & $19(17.6 \%)$ & $15 \quad(78.9 \%)$ & $4 \quad(21.1 \%)$ \\
\hline 7 & $8 \quad(7.4 \%)$ & $2(25.0 \%)$ & $\begin{array}{ll}6 & (75.0 \%)\end{array}$ \\
\hline 8 & $13(12.0 \%)$ & $11 \quad(84.6 \%)$ & $2(15.4 \%)$ \\
\hline 9 & $15(13.9 \%)$ & $11 \quad(73.3 \%)$ & $4 \quad(26.7 \%)$ \\
\hline 10 & $2 \quad(1.9 \%)$ & $2(100.0 \%)$ & $\begin{array}{ll}0 & (0.0 \%)\end{array}$ \\
\hline 11 & $3 \quad(2.8 \%)$ & $2(66.7 \%)$ & $1 \quad(33.3 \%)$ \\
\hline $\mathrm{DC}$ & $7 \quad(6.5 \%)$ & $5 \quad(71.4 \%)$ & $2(28.6 \%)$ \\
\hline Totals: & $108(100.0 \%)$ & $76(70.4 \%)$ & $32(29.6 \%)$ \\
\hline
\end{tabular}

\footnotetext{
${ }^{19}$ In an article criticizing the NLRA representation process, Weiler (1983) referred to discriminatory discharge as "the most powerful weapon in the employer's arsenal" (p. 1779), adding that "the dismissal of key union adherents gives a chilling edge to the warning that union representation is likely to be more trouble for the employees than it is worth"' (p. 1778).
} 
coefficients on these variables are negative, meaning that cases in the Second and Seventh circuits have a lower probability of being enforced than do cases in the other circuits, ceteris paribus.

As previously noted, the observation on the dependent variable is simply the answer "yes" or "no" to the question of whether or not the bargaining order was enforced by the court of appeals. Therefore, the observed dependent variable is assigned a value of 1 if the order in case $i$ was enforced and 0 if not $(i=1, \ldots, 108)$. Such a binary dependent variable suggests the binary probit model ${ }^{20}$ and can be summarized as:

$$
\text { ENFORCE }_{i}=\alpha+\sum_{j=1}^{k} \beta_{j} X_{i j}+\epsilon_{i}, \quad i=1, \ldots, 108
$$

where $E N F O R C E$ is the binary dependent variable, the $X$ 's are the independent variables that are hypothesized to affect the probability of enforcement, $\epsilon$ is a normally distributed error term, and $\alpha$ (the constant term) and the $\beta$ 's are the coefficients to be estimated by maximum likelihood. The specific form of equation (1) that was estimated is:

$$
\begin{aligned}
\text { ENFORCE }_{i}= & \alpha+\beta_{1} \text { USTRNGTH }_{i}+\beta_{2} D E M-A P P_{i}+\mathrm{B}_{3} \text { DISCHG }_{i} \\
& +\beta_{4} \text { THRCLS } S_{i}+\beta_{5} \text { THRDIS }_{i}+\mathrm{B}_{6} \text { GRNTBEN } \\
& +\beta_{7} \text { PROMBEN }_{i}+\beta_{8} \text { CIR }_{i}+\beta_{9} C I R 7_{i}+\epsilon_{i},
\end{aligned}
$$

where the subscript $i$ represents case number, with $i=1, \ldots, 108 .{ }^{21}$

\section{Results}

The coefficient estimates for the model presented in the previous section are reported in Table 3. These estimates must be interpreted carefully. They do not represent the effect on the probability of enforcement resulting from a one unit change in the corresponding independent variable as in a linear model. Rather, the change in the probability of enforcement resulting from a one unit change in an independent variable depends on the original probability of enforcement and, therefore, on the initial values of all the independent variables and on their estimated coefficients. More precisely, $\partial \operatorname{Prob}\left(y_{i}=1\right) / \partial x_{i j}=f\left(x^{\prime} \beta\right) \beta_{j}$, where $f(\cdot)$ is

\footnotetext{
${ }^{20}$ Alternatively, a logit model could be estimated in this framework. The difference between the binary probit and logit models is the assumption concerning the distribution of the random error term. The error term is assumed to follow a normal distribution in the probit model, whereas in the logit model, it is assumed to follow the extreme value distribution. Because both models are equally easy (in terms of computer time) to estimate, the probit model was chosen because the normal distribution for the error term is believed to be more realistic than the extreme value distribution implicitly assumed in the logit model.

${ }^{21}$ The variable CLOSE, representing the hallmark violation of plant closure, was not included in the estimating model. There were only three cases in which this violation occurred; therefore, the variable CLOSE is equal to zero for 105 of the 108 observations.
} 
the standard normal density function and $\operatorname{Prob}\left(y_{i}=1\right)$ ranges from zero to one. ${ }^{22}$ The above expression depends on the point at which $f\left(x^{\prime} \beta\right)$ is evaluated. Specifically, this expression will be higher at values of $x^{\prime} \beta$ that are close to the sample mean of $y(.704)$ and lower at probabilities of enforcement close to zero and one. Evaluations of these partial derivatives, in order to estimate the effects of changing values of the independent variables on the probability of enforcement, are presented in the last column of Table 3. These expressions are evaluated at the sample mean values of the variables.

\section{Table 3}

\section{Estimated Coefficients and Partial Derivatives Evaluated at Sample Means \\ (standard errors in parentheses)}

\begin{tabular}{lcc}
\hline Variable & Coefficient & $\begin{array}{c}\text { Partial } \\
\text { Derivative }\end{array}$ \\
\hline CONSTANT & -1.6741 & \\
USTRNGTH & $(1.1115)$ & $0.0088^{* *}$ \\
& $0.0282^{* *}$ & \\
DEM-APP & $(0.0122)$ & -0.0015 \\
DISCHG & -0.0048 & $0.1541^{*}$ \\
THRCLS & $(0.0116)$ & $0.2537^{* *}$ \\
THRDIS & $0.4949^{*}$ & \\
& $(0.3098)$ & 0.0195 \\
GRNTBEN & $0.8147^{* *}$ & $0.1540^{*}$ \\
PROMBEN & $(0.3165)$ & \\
CIR2 & 0.0627 & -0.0100 \\
CIR7 & $(0.3059)$ & \\
& $0.4943^{*}$ & $-0.3815^{* *}$ \\
& $(0.3225)$ & $-0.5043^{* *}$ \\
\hline
\end{tabular}

*significant at 10 percent level.

${ }^{* *}$ significant at 1 percent level.

\footnotetext{
${ }^{22}$ For a thorough, easy to follow explanation of the interpretation of probit coefficients, see Becker and Waldman (1987).
} 
Missing from the estimating model is the variable SIZE, measured as the number of employees in the bargaining unit. When this variable was included, it was found not to have a significant effect on the probability of enforcement. Furthermore, the inclusion of SIZE along with the variable USTRNGTH resulted in some multicollinearity in the estimation. This is due to the fact that the size of the bargaining unit is inversely related to the strength of employee support for the union. ${ }^{23}$

Employee support (USTRNGTH) was found to have a small, positive effect on the probability that a bargaining order will be enforced. This result can be interpreted in light of Cooper's (1984) findings concerning the relationship between the level of employee support and the likelihood of a union election victory. Cooper found evidence to indicate that majority employee support, measured the same way as the variable USTRNGTH, does not guarantee a union victory in an NLRB-conducted election. Still, Cooper found a direct relationship between the level of employee support and the probability of the union winning an election. In terms of the present study, the value of approximately .03 for the estimated coefficient on USTRNGTH indicates that at the mean levels of the explanatory variables a 10 percent increase in employee support for the union will result in the probability of enforcement increasing by approximately 0.088 .

It is not entirely clear why the level of employee support should increase a court's willingness to enforce a bargaining order. The critical inquiry is not the level of support (assuming it is at least a majority), but rather the effect of the employer's unlawful conduct. As speculated in Section II, a court may be more willing to defer to the Board's assumptions about the coercive effect of employer action when the union has had substantial support. That is, the court might be more willing to accept the Board's conclusion that a union's election loss was caused by coercion (rather than by a mere loss of interest) when it had previousiy garnered significant employee support.

Somewhat surprisingly, the length of time between a union's demand for recognition and the circuit court's decision was found to have no significant effect on the probability of enforcement. It was hypothesized that changed circumstances might decrease the probability of enforcement, especially because courts often refer to that factor in their non-enforcement decisions. The estimated coefficient on $D E M-A P P$, however, is close to zero, and it is insignificant in explaining the probability of enforcement. The components of $D E M-A P P(D E M-O R D$ and $O R D-A P P$ ) were included separately in other estimating equations, and neither was found to have a significant effect on the probability of enforcement. Despite some courts' assertions to the contrary, their failure to enforce bargaining orders cannot be accounted for by pointing to the changed circumstances doctrine. Rather, the courts appear to be using that doctrine to justify decisions actually reached on other grounds.

\footnotetext{
${ }^{23}$ Small units tend to have high employee support. The units with 100 percent support for the union ranged in size from 2 to 7 .
} 
Although the passage of time does not affect the chance of enforcement, it does appear to reduce a union's chances of successful negotiations with the employer. Even with an enforcement rate of over 70 percent, employers still benefit when courts review bargaining order cases. Besides simply putting off the bargaining obligation, evidence suggests that the delay contributes a more significant effect. In some appealed cases, a substantial number of union supporters leave the work force before judicial enforcement. At the time of the court's order, then, the bargaining unit is comprised of many employees who were not working for the employer during the union organizing campaign. This causes some unions to abandon the bargaining relationship because of a lack of employee support. ${ }^{24}$

The most consequential hallmark violations were discriminatory discharge, threat of plant closure, and grant of benefits. The effects of these unfair labor practices were found to be positive and significant in explaining the probability of enforcement. A case in which a discriminatory discharge was committed (not considering how many employees were discharged) is estimated to have a 0.154 more probable chance of being enforced than a case in which no discriminatory discharge took place. The presence of the threat of plant closure is estimated to increase the probability of enforcement by 0.254 , and the grant of benefits raises the probability of enforcement by an estimated 0.154 , which is the same as the estimated effect of discriminatory discharge.

These findings, however, do not necessarily mean that the courts defer to NLRB decisions concerning the effect of unfair labor practices. They may merely indicate that the courts agree with the Board's assumptions about the effect of certain actions. This analysis is supported by noting that unfair labor practices, other than the three mentioned above, had no significant effect on the probability of enforcement. This might indicate that the courts are making their own estimation of the likely effect of an employer's conduct rather than deferring to the Board's assessments. Such action clearly could not be justified under the standard of review established by the Supreme Court.

As expected, bargaining order cases that were heard in the Second and Seventh circuits have significantly lower probabilities of enforcement than those reviewed by other circuits. Cases going to the Second Circuit are estimated to have a 0.382 lower probability of being enforced than do other cases. For the Seventh Circuit, the estimated effect on the probability of enforcement is to lower it by a factor of 0.504 . Closer examination of the opinions written in the Second and Seventh circuit cases sheds some light on the reasons for these lower enforcement rates. Based on the circuit court opinions used in this study, it appears that

\footnotetext{
${ }^{24}$ This evidence is based on preliminary data collection for a project that examines unions that have been brought about by bargaining orders and compares these unions with unions that were elected during the same time-period. Many of the bargaining order unions have abandoned their bargaining relationship with the employer, citing lack of employee support, due to substantial employee turnover since the employer's unfair labor practice campaign, as the reason for abandonment.
} 
the Second and Seventh circuits place unrealistically high explanation requirements on the Board in bargaining order cases, resulting in these circuits enforcing smaller proportions of bargaining orders than any of the other circuits.

Given the reduced probability that orders heard by the Second and Seventh circuits will be enforced, employers located within those jurisdictions have considerable incentive to seek judicial review. This is especially true given the tendency of both circuits to mention delay in the assessment of an order's propriety. Conversely, to the extent that forum shopping is possible, union representatives should make an effort to avoid having bargaining order appeals heard in the Second and Seventh circuits. ${ }^{25}$

\section{Concluding Comments}

An examination of the factors that determine whether or not an NLRB bargaining order will be enforced by the court of appeals revealed some interesting results. The most significant effect on the probability of enforcement was determined to be the circuit in which the case was heard. Both the Second and the Seventh circuits have much lower enforcement rates in bargaining order cases than do any of the other circuits.

Other significant factors include the level of employee support for the union and the type of hallmark violations committed by the employer. The directions of the effects of each of these factors were as expected. The most significant hallmark violations were found to be discriminatory discharge, threat of plant closure, and grant of benefits. The presence of any of these unfair labor practices increased the probability of enforcement by over 0.15 . It was also found that the lengths of the judicial delays in bargaining order cases do not reduce the probability of enforcement, despite the occasional mention of changed circumstances as a justification for overturning the NLRB's bargaining order decisions.

Much empirical research still needs to be done in the area of bargaining orders. Other topics include the comparison of unions that were installed as a result of bargaining orders with those that were elected by the employces in an NLRB-conducted election. This topic is currently being researched and promises to shed more light on the controversy surrounding bargaining orders.

\footnotetext{
${ }^{25}$ Section 10(f) of the Act authorizes "any person aggrieved" by an NLRB unfair labor practice order (typically the losing party) to seek review in the circuit court of appeals "wherein the unfair labor practice was alleged to have been engaged in or wherein such person resides or transacts business, or in the United States Court of Appeals for the District of Columbia." Similarly, under Section 10(e), the Board can seek review either in the circuit where the unfair labor practice occurred or where the employer "resides or transacts business."
} 


\section{REFERENCES}

Becker, W. E. and D. M. Waldman. "The Probit Model." In Econometric Modelling in Economic Education Research. Edited by Becker and Walstad. Kluwer-Nijhoff Publishing, Boston, 1987.

Bethel, T. "Profiting from Unfair Labor Practices: The Reagan Influence." Indiana Law Journal 60 (1984): 227.

and C.A. Melfi. "Judicial Enforcement of NLRB Bargaining Orders: What Influences the Court?"' University of California Davis Law Review, November 1988.

Cooper, L. "Authorization Cards and Union Representation Election Outcomes: An Empirical Assessment of the Assumption Underlying the Supreme Court's Gissel Decision." Northwestern University Law Review 79 (1984): 87.

Getman, J., S. Goldberg, and J. Herman. "NLRB Regulation of Campaign Tactics: The Behavioral Assumptions on Which the Board Regulates." Stanford Law Review 27 (1975): 1465. York, 1976.

Weiler, P. "Promises to Keep: Securing Workers' Rights to Self-Organization Under the NLRA." Harvard Law Review 96 (1983): 1769. 